\title{
EFFECTIVENESS OF SUBCONJUNCTIVAL BEVACIZUMAB ASSOCIATED WITH A LASER - BASED PROCEDURE IN THE TREATMENT OF NEOVASCULAR GLAUCOMA
}

\author{
MARIA ALEXANDRA PREDA ${ }^{1 *}$, GHEORGHITA POPA ${ }^{1 \#}$, OLIMPIU L. KARANCSI ${ }^{2 *} *$, \\ OVIDIU MUSAT $^{3 \#}$, STELLA IOANA POPESCU ${ }^{3 \#}$, MIHNEA MUNTEANU $^{1 \#}$, ZORAN POPA $^{4 \#}$ \\ IDepartment of Ophthalmology, "Victor Babeş" University of Medicine and Pharmacy, Timișoara, Romania \\ ${ }^{2}$ Department of Oral Implantology and Prosthetic Restorations on Implants, "Victor Babes" University of Medicine and \\ Pharmacy, Timișoara, Romania \\ ${ }^{3}$ Department of Ophthalmology, "Dr. Carol Davila” Central Military Emergency University Hospital, Bucharest, Romania \\ ${ }^{4}$ Department of Obstetrics and Gynaecology, "Victor Babes" University of Medicine and Pharmacy, Timișoara, Romania \\ *corresponding author: olilk@yahoo.com \\ \#All authors have equal contribution
}

Manuscript received: February 2018

\begin{abstract}
Micropulse transscleral diode laser cyclophotocoagulation (mTSCPC) is an established method of treatment for refractory glaucoma. This study evaluates the efficacy and safety of subconjunctival bevacizumab associated with mTSCPC versus mTSCPC alone. A number of six patients with neovascular glaucoma were treated with mTSCPC, three patients being treated with mTSCPC alone and three patients being treated with combination of mTSCPC and subconjunctival bevacizumab. The intraocular pressure (IOP), visual acuity, number of medications were monitored for 6 months. Complications that include visual acuity decline, prolonged anterior chamber inflammation and ocular pain were evaluated during the 6 months follow-up. No significant difference was found between the two groups at baseline $(\mathrm{p}=0.82)$ or final follow up $(\mathrm{p}=1)$ regarding the IOP reduction; neovascularisation regression was observed only in the combined therapy group (66.6\%). Micropulse transscleral cyclophotocoagulation with diode laser is an effective method of lowering intraocular pressure in cases of refractory glaucoma, with minimal ocular complications. Additionally, the association between mTSCPC and subconjunctival bevacizumab resulted in neovascularisation regression and IOP reduction.
\end{abstract}

\section{Rezumat}

Ciclofotocoagularea transsclerală micropulsată (mTSCPC) este o metodă de tratament pentru glaucomul refractar. Acest studiu evaluează eficacitatea şi siguranța bevacizumabului administrat subconjunctival asociat cu mTSCPC față de mTSCPC în monoterapie. Au fost incluşi în studiu şase pacienți cu glaucom neovascular, trei pacienți trataţi cu mTSCPC în monoterapie și trei pacienți tratați cu o combinație de mTSCPC și bevacizumab subconjunctival. Au fost monitorizate presiunea intraoculară (IOP) și acuitatea vizuală, timp de 6 luni. Nu s-a constatat o diferență semnificativă între cele două grupuri la momentul includerii în studiu $(\mathrm{p}=0,82)$, nici la finalul său $(\mathrm{p}=1)$, în ceea ce privește reducerea PIO. Regresia neovascularizării a fost observată numai în grupul de terapie combinată $(66,6 \%)$.

Keywords: neovascular glaucoma, micropulse transscleral cyclophotocoagulation, subconjunctival bevacizumab

\section{Introduction}

Neovascular glaucoma (NVG) is an aggressive process which appears as a result of iris neovascularisation. The aetiological factor is chronic retinal ischemia, which leads to the release of vascular endothelial growth factors that induce retinal, iris and anterior chamber angle neovascularization. The latter affects the aqueous outflow, initially producing and open angle glaucoma and later producing a secondary angle-closure glaucoma. Most common causes include: ischemic central retinal vein occlusion, diabetes mellitus, and arterial retinal vascular disease. The end stage neovascular glaucoma is severe, relentless and does not respond to pharmaceutical treatment. Micropulse trans-scleral cyclophotocoagulation with diode laser is an effective method of lowering intraocular pressure (IOP) in cases of refractory glaucoma [14]. Some authors report the average decrease of intraocular pressure at 6 months of $25.8 \pm 14.5 \mathrm{mmHg}$. In this context, the use of molecules with complex action mechanisms becomes a therapeutic option in treatment-refractory pathologies $[2,17]$. Using anti-vascular endothelial growth factor agents such as bevacizumab, the existing neovascularisation can be directly targeted [8]. Bevacizumab binds to vascular endothelial growth factor (VEGF), the key factor of vasculogenesis and angiogenesis, and, by consequence, inhibits the 
FARMACIA, 2018, Vol. 66, 4

bind of VEGF to its receptors Flt -1 (R-VEGF1) and KDR (R-VEGF2), at the surface of endothelial cells $[1,3,5]$. Taking into account that intravitreal injections may be complicated by further IOP elevation in patients with $\mathrm{NVG}$, we performed the bevacizumab injections subconjunctivally $[4,6]$.

\section{Materials and Methods}

\section{Study design}

Considering the fact that the association between subconjunctival bevacizumab and mTSCPC is rarely noted in the literature, we selected a small group of patients to evaluate the effects of the combined therapy in neovascular glaucoma. Six eyes of six patients were evaluated over a six month follow-up, throughout 2017. Inclusion criteria were neovascular glaucoma, the rubeosis, intraocular pressure more than $40 \mathrm{mmHg}$, followup data for 6 months, written informed consent and visual acuity of counting fingers or more. The study we conducted received the Ethics Committee approval, and all patients signed an informed consent regarding the administration of bevacizumab and mTSCPC. After precise information about the off-label nature of the ocular bevacizumab injections, and the possible risks of both $\mathrm{mTSCPC}$ and bevacizumab injections, such as retinal detachment, vitreous haemorrhage, endophthalmitis, ocular hypotonia, sympathetic ophthalmia and uveitis, informed consent was obtained $[9,10,12,16]$. The patients were divided in 2 groups, one which underwent mTSCPC alone and the other one treated with mTSCPC combined with subconjunctival bevacizumab. The first group consisted of three eyes of three patients and the other group contained three eyes of other three patients. $33.3 \%$ of eyes ( 1 of 3 ) from the first group and $66.6 \%$ of eyes ( 2 of 3 ) from the second group had received at least one treatment for the cause of neovascular glaucoma at baseline (Table I).

Table I

Clinical findings

$\begin{array}{ccc}\text { Parameter } & \begin{array}{c}\text { mTSCPC alone group } \\ (\mathbf{n}=\mathbf{3})(\%)\end{array} & \begin{array}{c}\text { mTSCPC and intravitreal } \\ \text { bevacizumab combination } \\ (\mathbf{n}=\mathbf{3})(\%)\end{array} \\ \text { Age } & 65 \text { years }(60,72,65) & 68 \text { years }(62,70,73) \\ \text { Gender } & 2 \mathrm{M}, 1 \mathrm{~F} & 1 \mathrm{M}, 2 \mathrm{~F} \\ \text { Male } & 2(66.6 \%) & 1(33.3 \%) \\ \text { Female } & 1(33.3 \%) & 2(66.6 \%) \\ \text { Eye involved } & & \\ \text { Right } & 2(66.6 \%) & 1(33.3 \%) \\ \text { Left } & 1(33.3 \%) & 2(66.6 \%) \\ \text { Diabetic retinopathy } & 1(33.3 \%) & 2(66.6 \%) \\ \text { Central retinal vein occlusion } & 2(66.6 \%) & 1(33.3 \%) \\ \text { Trabeculectomy } & 0 & 0 \\ \text { Vitrectomy } & 0 & 0 \\ \text { Retinal photocoagulation } & 1(33.3 \%) & 2(66.6 \%) \\ \text { mTSCPC } & 0 & 2(66.6 \%)\end{array}$

mTSCPC - micropulse transscleral cyclophotocoagulation.

Before the mTSCPC and combined therapy of mTSCPC with subconjunctival bevacizumab, all patients were using maximal topical anti-glaucoma medication. Moreover, two $(33.3 \%)$ patients were using systemic acetazolamide ( $250 \mathrm{mg}$ once a day). The patients' starting point findings are presented in Table I. Micropulse trans-scleral cyclophotocoagulation alone and the combined procedure with subconjunctival bevacizumab were performed in the operating theatre, under standard sterile conditions. For disinfection, povidone iodine was applied to the eyelid, periocular skin and $4 \mathrm{ml}$ retrobulbar anaesthesia with $2 \%$ lidocaine and $0.5 \%$ bupivicaine was performed. The sterile field and lid speculum were positioned, after which local antibiotic drops were spread on. Diode laser was applied using the MicroPulse ${ }^{\circledR}$ P3probe (Iridex Corporation, Mountain View, CA, USA) using a protocol of $240 \mathrm{~ms}$ x $2000 \mathrm{~mW}, 31.3 \%$ duty cycle. In the 3 eyes that underwent combination mTSCPC and subconjunctival bevacizumab, after the MTSCPC session, bevacizumab (was injected under the conjunctiva close to the corneal limbus in one or two quadrants using a 26 - gauge needle. Approximately $0.05 \mathrm{~mL}$ solution containing $1.25 \mathrm{mg}$ of bevacizumab was injected. The injection was performed after the mTSCPC procedure to avoid subconjunctival haemorrhage. At the end of the procedure, 
FARMACIA, 2018, Vol. 66, 4

netilmicin drops, cyclopentolate and prednisolone acetate $1 \%$ were instilled and an eyepad was applied overnight. Netilmicin, cyclopentolate and prednisolone acetate $1 \%$ were prescribed for 14 days after the procedure. Glaucoma medications were maintained unchanged. Ophthalmic examinations were performed at baseline and at follow-up visits which were made at 1 week, 1 month and 6 months after the procedures. These included best corrected visual acuity (BCVA), slit-lamp examination, and IOP measurements with the Goldmann applanation tonometer. One session of mTSCPC and one subconjunctival bevacizumab injection were performed during the 6 months follow-up.

Statistical analysis

Results are presented as mean \pm SD. Statistical analysis was performed using GraphPad Prism version 5.00 for Windows (GraphPad Software, San Diego California, USA, www.graphpad.com).
Wilcoxon rank sum test (matched pairs) was used for the statistical analysis, statistical significance was considered for $\mathrm{p}<0.05$.

\section{Results and Discussion}

The average age was 65 years $(60,72,65)$ in the first group (mTSCPC) alone and 68 years $(62,70$, 73 ) in the second group (mTSCPC combined with subconjunctival bevacizumab). The cause of neovascular glaucoma was in $50 \%$ of eyes due to diabetic retinopathy and in $50 \%$ of eyes due to central retinal vein occlusion. The combination group had a higher proportion of patients with history of retinal photocoagulation and intravitreal bevacizumab injections. No history of eye surgery was reported. The clinical results of this study are presented in Table II.

Table II

Clinical outcomes

\begin{tabular}{|c|c|c|c|}
\hline Parameter & $\begin{array}{l}\text { mTSCPC alone } \\
(\mathrm{n}=3)(\%)\end{array}$ & $\begin{array}{l}\text { mTSCPC and bevacizumab } \\
\text { combination }(n=3)(\%)\end{array}$ & Differences betwee \\
\hline \multicolumn{4}{|l|}{ Basal VA } \\
\hline $\mathrm{CF}$ & $2(66.6 \%)$ & $1(33.3 \%)$ & \\
\hline$\geq 0.1$ & $1(33.3 \%)$ & $2(66.6 \%)$ & \\
\hline \multicolumn{4}{|l|}{ VA at last visit } \\
\hline $\mathrm{CF}$ & $2(66.6 \%)$ & $1(33.3 \%)$ & \\
\hline$\geq 0.1$ & $1(33.3 \%)$ & $2(66.6 \%)$ & \\
\hline \multicolumn{4}{|l|}{ IOP $(\mathrm{mmHg})$} \\
\hline Average baseline & 45 & 46 & $\mathrm{p}=0.82$ \\
\hline Average at 1 month & 35 & 32 & $\mathrm{p}=0.38$ \\
\hline Average at last visit & 34 & 34 & $\mathrm{p}=1$ \\
\hline Average baseline & 3 & 3 & \\
\hline Average at last visit & 3 & 3 & \\
\hline Acetazolamide use & $1(33.3 \%)$ & $1(33.3 \%)$ & \\
\hline
\end{tabular}

The IOP oscillation from baseline to the last follow-up visit is presented in Table III for the two groups. The baseline average IOP in the MTSCPC group was $45.00 \pm 3.00 \mathrm{mmHg}$ and in the combined group was $46.00 \pm 3.61 \mathrm{mmHg}$. Moreover, the average IOP at 6 months, the last follow-up visit, in the mTSCPC group was $34.33 \pm 3.06 \mathrm{mmHg}$ and in the combined therapy group was $34.33 \pm 3.52$ $\mathrm{mmHg}$. There were no statistical relevant differences between the two groups, $\mathrm{p}$ value at baseline was 0.82 , and 1.00 at final follow up (Figure 1). 
FARMACIA, 2018, Vol. 66, 4

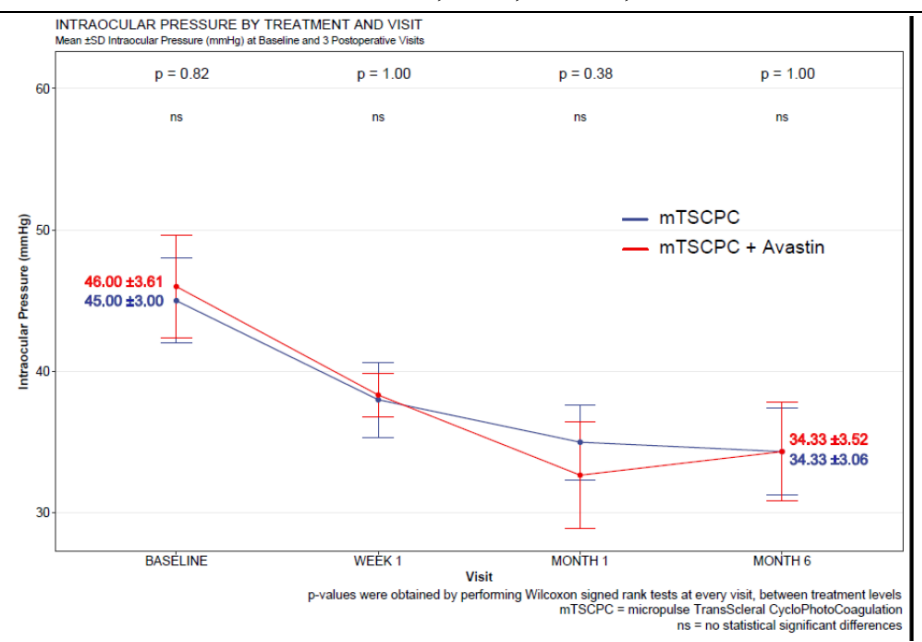

Figure 1.

IOP at baseline and last visit, comparison between the two groups

Comparing the average IOP of both groups at final visit, there are statistically significant baseline, and the average IOP of both groups at differences, $\mathrm{p}=0.031(\mathrm{p}<0.05)$ (Figure 2).

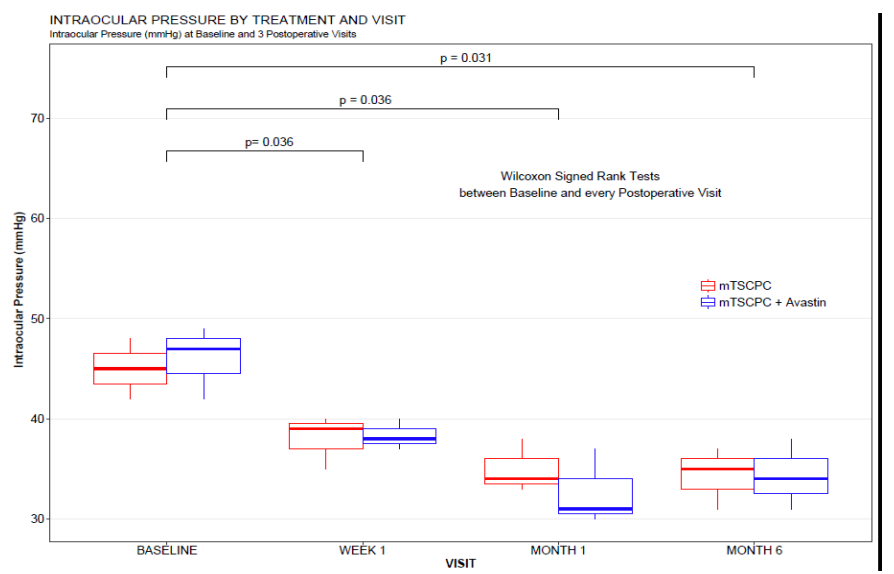

Figure 2.

IOP comparison between baseline and each follow-up visit

Regarding the best corrected visual acuity (BCVA), there were no differences between the baseline visual acuity and the last visit values (Table III). Rubeosis was an inclusion criterion, so $100 \%$ of the studied eyes presented iris neovascularisation at the starting point. On one hand, in the MTSCPC alone group, there were no changes in the neovascularisation distribution, on the other hand, in the combined therapy group, the neovascularisation distribution significantly reduced in $66.6 \%$.

Table III IOP variation $(\mathrm{mmHg})$

\begin{tabular}{|c|c|c|c|}
\hline Baseline IOP & $\begin{array}{c}\text { 1 week IOP } \\
(\mathrm{mmHG})\end{array}$ & $\begin{array}{c}1 \text { month IOP } \\
(\mathrm{mmHG})\end{array}$ & $\begin{array}{c}6 \text { months IOP } \\
(\mathrm{mmHG})\end{array}$ \\
\hline \multicolumn{4}{|c|}{ mTSCPC group } \\
\hline 45 & 39 & 34 & 35 \\
\hline 48 & 40 & 38 & 37 \\
\hline 42 & 35 & 33 & 31 \\
\hline \multicolumn{4}{|c|}{ mTSCPC combined with subconjunctival bevacizumab group } \\
\hline 47 & 37 & 31 & 34 \\
\hline 42 & 38 & 30 & 31 \\
\hline 49 & 40 & 37 & 38 \\
\hline
\end{tabular}

mTSCPC - micropulsetransscleral cyclophotocoagulation, IOP - intraocular pressure

In both groups, the average number of topical medication remained unchanged throughout the entire follow-up period. One patient from each group was under oral medication, before the 
FARMACIA, 2018, Vol. 66, 4

procedures, with anhydrase carbonic inhibitor (acetazolamide), and both of them required it at the end.

The management of NVG involves both reducing elevated intraocular pressure and treating the underlying disease that lead to the ischemic insult and initiates the anterior segment neovascularization. In the final stage of the disease the treatment is challenging. Bevacizumab is a $149 \mathrm{kDa}$ full-length immunoglobulin G1 antibody, that binds to and inhibits vascular endothelial growth factor (VEGF), decreasing the growth of neovessels [11]. When injected subconjunctivally, bevacizumab follows a straight transcleral route intraocularly or via conjunctival and lymphatic way. Na Kyung Ryoo et al reported three cases of neovascular glaucoma, treated with subconjunctival bevacizumab injections, where iris or angle neovascularization regressed considerably [14]. Some pharmacokinetic studies demonstrated that bevacizumab was present in the anterior chamber until one week after subconjunctival injections [15]. Administrating bevacizumab subconjunctivally is responsible for a rapid regression of iris and angle neovascularization and also for lowering the intraocular pressure, even though its effect is transient. Some studies present the association between $\mathrm{mTSCPC}$ and intravitreal bevacizumb injections. A retrospective case series by Ghosh et al presented 14 eyes in 12 patients, which were treated with transscleral cyclophoto-coagulation in combination with intravitreal bevacizumab for neovascular glaucoma. The conclusion of the study was that the combined procedure offers rapid control of anterior segment neovascularisation and good IOP control [7]. Kuhar S and Moster M performed a study on 19 patients with refractory glaucoma, and concluded that the average intraocular pressure decreased by $40.1 \%$ after the procedure. The patients were evaluated for an average of 60.3 days [13], Treatment outcomes of Micropulse TSCPC in Advanced Glaucoma (IQ81). In our study, the group that underwent only mTSCPC was monitored for 6 months and the average IOP drop was of approximately $23 \%$, and in the combined group the average IOP drop was of approximately $25 \%$.

Fong AW et al published in 2011 their results regarding the combination between TSCPC and intravitreal bevacizumab in neovascular glaucoma. The study outcome provided information such as the average reduction in intraocular pressure, which was of $33.5 \mathrm{mmHg}$ in the transscleral cyclophotocoagulation group and $23.7 \mathrm{mmHg}$ in the combination group, a difference of $9.8 \mathrm{mmHg}$. Neovascularisation was reduced in both groups. In the combined procedure group, 13 out of 20 eyes had complete regression of iris/angle neovascularisation at 6 months [4]. In our study, neovascularisation regression was observed only in the combined therapy group $66.6 \%$, probably suggesting that subconjunctival bevacizumab may provide an additional treatment option for NVG.

\section{Conclusions}

The major conclusion of our study is that both procedures used decrease the intraocular pressure. Additionally, the association between MTSCPC and subconjunctival bevacizumab resulted in neovascularisation regression and IOP reduction. In contrast to the literature, we decided to perform the bevacizumab subconjunctival, to prevent the potential IOP rise, done by the intravitreal injections, and also for the fact that we can better target iris neovascularisation with subconjunctival injections. The best corrected visual acuity was unchanged throughout the entire evaluation period. Iris neovascularisation was reduced in the combined therapy group, so we can suspect that this effect was due to subconjunctival bevacizumab injection. No ocular complication, such as ocular hypotony, sympathetic ophthalmia, endophthalmitis were present after the procedures were carried out. The initial antiglaucoma treatment was not modified. Our study highlights the necessity for further and more extensive study groups, regarding the combined therapy of mTSCPC and subconjunctival bevacizumab.

\section{References}

1. Aydin R, Tezel TH, Use of intravitreal bevacizumab for the treatment of secondary glaucoma caused by metastatic iris tumor. $J$ Glaucoma, 2018; 27(6): e113-e116.

2. Drăgoi CM, Olaru TO, Dinu M, Popescu C, Arsene AL, Dune A, Nicolae AC, Ancuceanu RV, Zbârcea CE, Negreș S, Nițulescu GM, Șeremet OC, Characterisation, pharmacotoxicological and biochemical studies on morus alba 1 . extract and its fractions. Farmacia, 2018; 66(1):120-128.

3. Ellis LM, Mechanisms of action of bevacizumab as a component of therapy for metastatic colorectal cancer. Semin Oncol., 2006;33(5Suppl10): S1-S7.

4. Fong AW, Lee GA, O'Rourke P, Thomas R, Management of neovascular glaucoma with transscleral cyclophotocoagulation with diode laser alone versus combination transscleral cyclophotocoagulation with diode laser and intravitreal bevacizumab. Clin Exp Ophthalmol., 2011; 39(4): 318-323.

5. Francis JH, Slakter JS, Abramson DH, Odrich SA, Gobin YP, Treatment of juxtapapillary hemangioblastoma by intra-arterial (ophthalmic artery) chemotherapy with bevacizumab. Am J Ophthalmol Case Rep., 2018; 11: 49-51.

6. Fung AE, Rosenfeld PJ, Reichel E, The international intravitreal bevacizumab safety survey: using the internet to assess drug safety worldwide. $\mathrm{Br} J$ Ophthalmol., 2006; 90: 1344-1349.

7. Ghosh S, Singh D, Ruddle JB, Shiu M, Coote MA, Crowston JG, Combined diode laser cyclocoagulation 
and intravitreal bevacizumab (Avastin) in neovascular glaucoma. Clin Experiment Ophthalmol., 2010; 38: 353-357.

8. Good TJ, Kimura AE, Mandava N, Kahook MY, Sustained elevation of intraocular pressure after intravitreal injections of anti-VEGF agents. $\mathrm{Br} J$ Ophthalmol., 2011; 95:1111-1114.

9. Iliev ME, Gerber S, Long-term outcome of transscleral diode laser photocoagulation in refractory glaucoma. Br J Ophthalmol., 2007; 91: 1631-1635.

10. Ip MS, Scott IU, Brown GC, Brown MM, Ho AC, Huang SS, Recchia FM, American Academy of Ophthalmology, Anti-vascular endothelial growth factor pharmacotherapy for age-related macular degeneration: a report by the American Academy of Ophthalmology. Ophthalmology, 2008; 115: $1837-1846$

11. Komori S, Sawada A, Oguni T, Mochizuki K, Ohkusu K, Case of endophthalmitis following intravitreal injections of bevacizumab. Clin Ophthalmol., 2010; 4: 773-775.

12. Kosoko O, Gaasterland DE, Pollack IP, Enger CL, Long-term outcome of initial ciliary ablation with contact diode laser transscleral cyclophotocoagulation for severe glaucoma. The Diode Laser
Ciliary Ablation Study Group. Ophthalmology, 1996; 103: 1294-302.

13. Kuhar S and Moster M, Treatment outcomes of Micropulse TSCPC in advanced glaucoma (IQ810/ MP). Laser Med Science, 2015; 31: 393-396.

14. Na Kyung Ryoo, Eun Ji Lee, Tae-Woo Kim, Regression of iris neovascularization after subconjunctival injection of bevacizumab. Korean $J$ Ophthalmol., 2013; 27(4): 299-303.

15. Nomoto H, Shiraga F, Kuno N, Kimura E, Fujii S, Shinomiya K, Nugent AK, Hirooka K, Baba T, Pharmacokinetics of bevacizumab after topical, subconjunctival, and intravitreal administration in rabbits. Invest Ophthalmol Vis Sci., 2009; 50: 48074813.

16. Yildirim N, Yalvac IS, Sahin A, Ozer A, Bosca T, A comparative study between diode laser cyclophotocoagulation and the Ahmed glaucoma valve implant in neovascular glaucoma - a long-term follow-up. J Glaucoma., 2009; 18(3): 192-196.

17. Zbârcea CE, Chiriţă C, Negreş S, Şeremet OC, Ștefănescu E, Ancuceanu RV, Olaru OT, Dinu M, Effects of topical application of dry extracts on allergic contact dermatitis induced by 2,4dinitrofluorobenzene, in balb/C mice. Farmacia, 2017; 65(6): 862-867. 